\title{
PROBLEMS FACED BY A NATIONAL WATER UTILITY IN AN URBAN AREA, CASE STUDY: TEGUCIGALPA, HONDURAS*
}

\author{
Z. COELLO-BALTHASAR ${ }^{1,2,3}, \&$ B. BALFORS ${ }^{1}$ \\ ${ }^{1}$ Department of Land and Water Resources Engineering, Royal Institute of Technology, Sweden. \\ ${ }^{2}$ School of Geographical and Earth Sciences, University of Glasgow, UK. \\ ${ }^{3}$ Facultad de Ingeniería, Universidad Nacional Autónoma de Honduras, Honduras.
}

\begin{abstract}
The capital of Honduras, Tegucigalpa, has suffered a shortage of piped water, since the 1980s. The national utility company in charge of supply, SANAA, opted to supply water intermittently, which poses a problem for the population who cannot afford water storage facilities. Interviews were conducted with the various authorities involved in the water sector to reveal why SANAA has not been able to incorporate new sources of water and therefore satisfy the needs of the growing population. The research revealed that SANAA's operations have been hindered by the fast and unorganized growth of the city, the failure of other governmental agencies to comply with their mission efficiently, and also by the intervention of the Central Government in its operations. Stability of SANAA's management and coordination between governmental agencies are essential for the efficient operation and long-term planning of and investment in the water sector.

Keywords: Honduras, intermittent water supply, patronage, SANAA, Tegucigalpa, water utility.
\end{abstract}

\section{INTRODUCTION}

The seventh of the Millennium Development Goals includes the target 'Halve, by 2015, the proportion of the population without sustainable access to safe drinking water and basic sanitation'. The achievement of this lies mainly in the monopoly of public providers whose supply service has been characterized by low quality and inadequate coverage, and their operational practices are inefficient, with poor cost recovery, high labor costs, low labor productivity, and large state subsidies that benefit mainly the middle class and the wealthy $[1,2]$.

Research trying to identify the causes leading to deficient urban water supply services has lead to the analysis of the operation of water utilities. Defects, such as the juxtaposition of regulatory and operational roles in state-owned enterprises and a politicization of water utilities [3], result in a poor service with little expansion. Politicization has been described as making decisions based on political, rather than technical or commercial criteria, keeping the price of the service below sustainable level [4], demanding special investments, purchases or recruitment of employees [5]. Additionally, other problems, which independently or in an interrelated manner cause water supply problems, include, a high rate of population growth, lack of investment in water supply infrastructure, and the availability of water sources [6].

In the case of Honduras, the task of providing potable water lies either with the National Autonomous Service of Aqueducts and Sewage Systems (Servicio Autónomo de Acueductos y Alcantarillados, SANAA) or with the local municipalities. SANAA has been the national public authority responsible for administrating, planning, and handling the water supply and waste water in Honduras, since its creation in 1961. Although the municipalities were supposed to transfer their water supply systems to SANAA, this transfer did not entirely take place. SANAA operated 31 water

\footnotetext{
* Revised version of the paper "Assessment of causes leading to an insufficient water supply in Tegucigalpa, Honduras" presented in the conference Water Resources Management 2011, Riverside, California 
supply systems (which supply approximately $64 \%$ of the national population), while 271 systems remained in local municipalities' hands [7]. Reforms during the last decades have devolved the water supply to the municipalities in an attempt to improve the quality of the service.

SANAA's role as administrator and planner was criticized for its biased distribution of financial resources favoring the urban areas [8]. However, the biggest urban center in the country, with more than one million inhabitants [9], the capital of Honduras, Tegucigalpa, has severe water deficit. The water supply system for Tegucigalpa relies on two main water reservoirs: Concepción, with a storage capacity of $33 \mathrm{Mm}^{3}$, and Los Laureles with a capacity of $12 \mathrm{Mm}^{3}$ [10]; other minor sources, such as wells, springs, and rivers also supply water to the treatment plants of Picacho and Miraflores. History has revealed that when a new source of water has been incorporated to supply Tegucigalpa, it has been a reaction to an already existing deficit [11]. Since the construction of Concepción in 1991, no significant source of water has been added to the system. During that time, the population of Tegucigalpa has continued to grow, increasing the demand for water.

As far back as the 1980s, SANAA introduced an intermittent water supply service to cope with a permanent drinking water shortage [12]. Currently this can be as severe as providing water for only 6 to $8 \mathrm{~h}$ every third day [13]. The intermittent service poses a major problem for the $15.1 \%$ of the inhabitants below the poverty line [14] who are unable to afford water storage facilities. Moreover, the habitants of the city are also exposed to polluted water owing to leaks in the pipes that are empty during the prolonged periods of interrupted supply [15].

This paper will analyze and discuss the reasons that have lead to the water shortage in Tegucigalpa. It will seek to demonstrate that the causes of a deficient water supply are not just limited to administrative problems in the utility but also the result of complex factors, which together have impeded the efficient performance of the water utility.

\section{METHODOLOGY}

The research question was addressed by a case study. This research method requires data collection techniques using multiple sources of evidence to provide cross-data validity checks and test for consistency, thus performing triangulation [16]. The selected sources of information for this research were open-ended interviews and documentation. Open-ended questions allow the respondent to communicate a synthesis of years of participant observation and personal inquiry freely, spontaneously, and in their own language instead of being forced to adapt to preconceived answers [17], whereas documents are important to provide specific facts, and to corroborate and augment evidence from other sources [16].

Interviews were carried out in Tegucigalpa between April 12 and May 9, 2010 to actors identified in the actual decision-making process in the water sector: officials of SANAA; of the coordinator agency, the National Water and Sanitation Council (Consejo Nacional de Agua Potable y Saneamiento, CONASA); and of the regulator agency, the Regulatory Entity for the Drinking Water and Sanitation Sector (Ente Regulador de los Servicios de Agua Potable y Saneamiento, ERSAPS). Additional interviews were held with a consultant of SANAA, with two persons in charge of water treatment plants and reservoirs, two SANAA trade union leaders (Sindicato Nacional de Trabajadores del SANAA y Similares, SITRASANAAYS) and with the director of AMITIGRA, a NGO concerned with the environmental protection of La Tigra national park, the site of the springs that feed the Picacho water plant. Due to the organizational complexity of SANAA, the snowball sampling technique was used as a method to identify interviewees. This technique consists of locating one or more key individuals and asking them to name others who would be likely candidates for the research [18]. The snowball sampling technique resulted in seven interviews with managers and two employees of different units of SANAA. The first person selected to be interviewed using this 
technique was the Sub-Manager, due to his considerable influence in the decision-making process of SANAA. The total of 17 interviews was considered to be sufficient because the sampling can be terminated when no new information is forthcoming from additional sampling units [19]. The approach used to collect data through open-ended interviews involved drawing up a list of semistructured questions prior to each interview, as a reminder of the information which needed to be collected, to make sure that all relevant topics would be covered with each respondent and also to make sure that the same basic lines of inquiry were pursued with each interviewee $[16,19]$.

Due to the time restrictions of the interviewees, focused interviews were applied to collect data. Data from interviews might pose limitations, such as personal bias, politics, lack of awareness of the interviewee at the time of the interview, and recall errors [19]. A reasonable approach to overcome such limitations is to corroborate interview data with information from other sources [16].

Documents were used as a good source of information to corroborate and augment evidence from other sources [16]. Relevant documents included newspaper articles, law decrees, reports from CONASA, ERSAPS, SITRASANAAYS, and consultant companies, such as the Societe Grenobloise d'Etudes et d'Application Hydrauliques (SOGREAH) and Pacific Consultants International (PCI), work from different researchers, and online reports from the World Bank and the InterAmerican Development Bank (IBD). Data triangulation was performed through a systematic search and review of documents.

An inductive analysis was carried out of the resulting interviews to search for recurrent patterns which could be grouped into categories. Inductive analysis involves discovering patterns in the data without making prior assumptions about the linear or correlative relationships among variables [19]. Moreover, the relative frequency was estimated for each category based on the number of interviewees who mentioned each problem. Finally, case study evidence was examined to discover causal links and build explanations.

\section{RESULTS AND DISCUSSION}

In the course of the interviews 13 distinct problems were independently identified by the interviewees (Table 1). An inductive analysis produced four categories to explain the causes of the piped water scarcity in Tegucigalpa (Table 2). The analysis highlighted general trends to attribute the lack of drinking water to financial limitations $(57.1 \%)$, particularly the low price of the water service $(18.4 \%)$ and the excessive number of employees in SANAA who drained the available financial resources $(14.3 \%)$. The other tendency was to relate the shortage of water to population growth $(24.5 \%)$. An analysis of these points follows, starting with rainfall uncertainty. The lack of cooperation with the municipality and the loss of continuity of programs will be discussed further in this paper because these points proved to be interrelated with other problems.

\subsection{Rainfall uncertainty}

Tegucigalpa receives about $1,100 \mathrm{~mm}$ of precipitation per year, but this is distributed unevenly over the year, with as low as $4 \mathrm{~mm}$ during the months of the dry season (November-April) and $163 \mathrm{~mm}$ during the months of the rainy season (May-October) [20]. Ideally, existing reservoirs should fill up during the rainy season and the water last throughout the dry season. Delays in the onset of the rainy season increase the stress on SANAA. Interviewees stated that a challenge for SANAA is the uncertainty over the extent of the dry season, or whether the amount of rain during the wet season will be sufficient to fill up the reservoirs. In the current situation, where an intermittent water supply is in practice even when the reservoirs are at full capacity, an extended dry season results in a decrease in the hours of supply. Water storage during the rainy season is the most effective way to ensure water 
Table 1: Problems highlighted during the interviews.

\begin{tabular}{lccc}
\hline & \multicolumn{2}{c}{ Interviews } & \\
\cline { 2 - 3 } Problems & Snowball & Others & Total \\
\hline Subsidized tariff & 7 & 2 & 9 \\
Number of personnel & 3 & 4 & 7 \\
Deterioration of water sources & 1 & 3 & 4 \\
Lack of financial support from the central & 3 & 1 & 4 \\
$\quad$ government & 3 & 1 & 4 \\
Lack of municipality cooperation & 2 & 1 & 3 \\
Increasing water demand & 1 & 2 & 3 \\
Lack of a decentralized administration & 3 & 0 & 3 \\
Physical and commercial losses & & & 3 \\
$\quad$ (high unaccounted water) & 1 & 2 & 3 \\
Rainfall uncertainty & 3 & 0 & 2 \\
Settlements in high areas & 1 & 1 & 2 \\
Competing needs & 2 & 0 & \\
Dependence on international financial aid & 2 & 0 & \\
Lack of continuity of programs & & & 3 \\
\hline
\end{tabular}

Table 2: Relative frequency of the different categories produced by the inductive analysis.

\begin{tabular}{llccc}
\hline Category & \multicolumn{1}{c}{ Problem } & $\begin{array}{c}\text { Times } \\
\text { mentioned }\end{array}$ & $\begin{array}{c}\text { Relative } \\
\text { frequency (\%) }\end{array}$ & $\begin{array}{c}\text { Relative } \\
\text { frequency (\%) }\end{array}$ \\
\hline Financial & Subsidized tariff & 9 & 18.4 & 57.1 \\
limitations & Number of personnel & 7 & 14.3 & \\
& Lack of financial support from the & 4 & 8.2 & \\
& $\quad$ central government & & & \\
& Lack of a decentralized & 3 & 6.1 & \\
$\quad$ administration & & & \\
& Physical and commercial losses & 3 & 6.1 & \\
& Dependence on international & 2 & 4.1 & \\
Population & $\quad$ financial aid & & & \\
growth & Seterioration of water sources & 4 & 8.2 & \\
& Settlements in high areas & 3 & 6.1 & \\
& Increasing water demand & 3 & 6.1 & \\
Political & Competing needs & 2 & 4.1 & \\
& Lack of municipality cooperation & 4 & 8.2 & \\
Indirect & Lack of continuity of programs & 2 & 4.1 & \\
\hline & Rainfall uncertainty & 3 & 6.1 & \\
\hline
\end{tabular}


availability during the dry season. However, it is evident that if SANAA has opted to use an intermittent water supply, then the storage capacity at present is insufficient to provide a continuous supply to Tegucigalpa.

\subsection{Implications of population growth}

Population growth represents a challenge to SANAA because of the implications attached. A first and direct implication brought up during the interviews is that while the population continues to grow, water resources remained largely constant since the construction of the Concepción reservoir in 1991. As one interviewee expressed, 'It is a redistribution of what we have, that is all what we can do'. SANAA needs to deliver a greater volume of water to households to satisfy their needs.

A second implication is that new settlements are growing in an unorganized and unplanned way, occupying either the high mountainous areas, to which supply is difficult or onto protected areas with water supply potential. In spite of Tegucigalpa's site not being favorable for urban expansion (i.e. surrounded by mountains, a highly irregular topography, prone to landslides, and few valleys [12]), the urban area has more than tripled over the past 25 years [21]. The growth has taken the form of informal illegal settlements growing at the edges of the urban core, in areas with steep slopes and irregular land tenure [22]. Areas above an elevation of 1,150 $\mathrm{m}$ above sea level present a problem for SANAA, as piped water needs to be pumped up for which no funding is available [21]. Although the Municipality has the responsibility to control these settlements, they lack the financial and technical resources to do so. This has led to the situation that $60 \%$ of the land in Tegucigalpa has no clear ownership, $46 \%$ of all current residential properties were obtained through illegal land invasion, $8 \%$ of the settlements are in areas higher than the legal limit of 1,150 m and urban expansion has already started to penetrate protected areas with water supply potential, such as the Guacerique River watershed [21]. Piped water will not be provided to these settlements unless legal land tenure can be demonstrated [23].

The third and fourth implication of population growth brought up by the interviewees is that SANAA not only has to compete for available water resources with other activities, such as agriculture and industry, but also has to protect potential new sources of water supply from the damage inflicted by those activities. Even though the General Water Law of 2009 (Ley General de Aguas) prioritizes the usage of water for human consumption above any other needs, because the catchment division does not follow the political divisions, not all sources of water are available to supply Tegucigalpa since the neighboring municipalities have needs of their own. This implies SANAA has a constant battle against water extraction for agricultural or industrial purposes, for forestry protection and agreements with other municipalities.

Settlements in the areas with water supply potential for Tegucigalpa present multiple problems for SANAA. Not only do they cause deforestation but they also are an additional source of pollution due to the improper disposal of waste water. Furthermore, in the case of the construction of a dam, the habitants settled in the flooded area will demand compensatory payments, thereby increasing of the costs of the project.

In 1972, when all of the catchment areas with water supply potential were gradually declared protected by the Forestry Law, a problem was created for the habitants of those areas. A consultancy performed by the Italian Engineering Society [24] revealed that this population depended on the forestry industry. During the 1980s, when the implementation of the law was monitored in certain areas, the habitants had to shift to agricultural practices. The habitants saw agriculture as an alternative not only for subsistence but also as a source of income from the accessible and growing market of Tegucigalpa. Excessive use of fertilizers and pesticides have allowed that land suitable for forestry 
is now used intensively for crop production leading to soil degradation and water pollution, such as the case of Los Laureles. The Los Laureles reservoir suffers from occasional algae blooms and excessive growth of water hyacinths which proliferate and then taint the drinking water with decaying organic material affecting the color, taste and odor and, therefore, increase the cost of water treatment water [25]. Moreover, upstream water extraction for irrigation purposes is considerable but has not been quantified [26].

The protection of catchments, according to the General Law of the Environment of 1993, is a shared responsibility among different governmental agencies called The National Network of Hydrographical Catchments (Red Nacional de Cuencas Hidrográficas). The Network is coordinated by the Secretariat for Natural Resources (Secretaría de Recursos Naturales, SERNA) together with the Honduran Corporation for Forestry Development (Corporación Hondureña de Desarrollo Forestal, COHDEFOR). SERNA coordinates environmental management policies whereas, according to the Forestry Law of 1974, COHDEFOR was responsible for the management and protection of the forestry resources. The duties of COHDEFOR were later transferred to the Institute of Forestry Conservation (Instituto de Conservación Forestal, ICF), when COHDEFOR ceased to exist in 2008. Even if SANAA forms part of the network, it has been powerless in the fight to prevent authorized construction in the protected sub-catchments, such as La Tigra and Guacerique.

The small creeks, whose water is directed to El Picacho for incorporation in the water supply of Tegucigalpa, are born in La Tigra. La Tigra is a mountainous area shared among five neighboring municipalities, including Tegucigalpa and Santa Lucía. In 1993, AMITIGRA, an NGO whose sole objective is to protect La Tigra, was created. Then, a local newspaper [27] described the events that started in 2004 when a construction company applied to SERNA and COHDEFOR for permission to start the construction of 25 luxurious chalets in the area of La Tigra corresponding to the Santa Lucía Municipality. Authorizations were granted and the construction started the next year. The project was stopped due to media pressure. Both COHDEFOR and SERNA then withdrew their authorization. The construction company started a lawsuit process which ended when the Supreme Court of Honduras granted the right to continue with the construction of the chalets.

Another case of a protected area threatened by authorized construction is the Guacerique watershed. The Guacerique watershed is where the previously described project of Guacerique was going to be built, where the Laureles water reservoir is located and where the new Guacerique II project is planned to be built. The Guacerique catchment was declared a protected forestry zone in 1973. In spite of this status, Lee [25] described several changes in the watershed that now threaten Los Laureles and the feasibility of Guacerique II. The changes include (a) the construction of a low-income housing project known as Ciudad Mateo on the hill slopes fringing Los Laureles Reservoir. Ciudad Mateo represents a constant threat to the water supply of the city due to the increase of sedimentation of Los Laureles reservoir and also the risk of leakages from sewage water pipes on the surface alongside the edge of the reservoir. For these reasons the project was stopped when 2,300 houses had already been built; it has remained uninhabited ever since. Then and now it has been the focus of controversy over whether they should be inhabited or demolished [28]. (b) The routing of the city's major peripheral transport route along the edge of the reservoir, which was authorized by the Public Works and Transport Ministry (Secretaría de Obras Públicas y Transporte, SECOPT), and whose plans failed to include environmental mitigation. (c) The development of large poultry farms immediately upstream of Los Laureles. (d) The construction of military facilities along tributary streams and in the flood area of Guacerique II including: the Honduran Military Academy, the Centre for Military Logistic Support, the Honduran Military Industry Complex, the Fourth Infantry Battalion, the Discua-Elvir Military Hospital, the National Police Academy, among others, all of which were constructed with only basic sanitary sewer systems collecting wastewater and conducting it to 
adjacent water courses that lead into Los Laureles reservoir. (e) The commercial extraction, both legal and illegal, of firewood from headwaters. The cost of building Guacerique II had been estimated to be approximately US $\$ 130$ million, whereas the compensatory expenses are the equivalent of US\$168 million [26]. Nowadays, the original plans have been modified and the storage capacity has been changed from 83 to $45 \mathrm{Mm}^{3}$ to reduce compensation payments to the people and installations in the flood area [29].

The failure of governmental agencies to comply with their mission, such as COHDEFOR's failure to protect the areas with water supply potential, has caused serious implications for SANAA. The areas which were meant to be protected are now occupied by installations and SANAA has to pay high compensatory expenses. SANAA is therefore left with alternatives such as building projects with lower storage capacity in further places or struggling to find someone to finance the compensatory expenses. Until the decision is taken, the few potential sources of water are subject to further deterioration originating from pollution and deforestation, while the illegal settlements are growing.

\subsection{Lack of cooperation from the municipality}

Interviewees mentioned conflict between SANAA and the municipality. Two situations highlight this statement. The first is when the municipality authorizes settlements in high or protected areas of the city. The second situation is when SANAA has to invest resources to create and update the database of new construction in the city with information handled by the municipality. 'The municipality and SANAA have traditionally been antagonists, and there has been little cooperation', according to one of the interviewees.

Although the municipality has the responsibility to control illegal settlements, they lack logistics to do so [21]. When it comes to new legal construction or urbanization, the owner must obtain authorization to start building from the municipality and from SANAA. The municipality, as well as SANAA, face the same problem of construction owners failing to comply and legalize the buildings [30, 31]. The municipality, as well as SANAA, punishes evaders with fines.

This rivalry between SANAA and the municipality could be explained from a historic perspective, given the reform of the water sector. In the case of Tegucigalpa, several attempts have been made to reform water administration by transferring the authority via municipal level. Beyond the particular problems of water availability in Tegucigalpa, the municipalization process was initiated in 1990 when the National Congress passed the Municipal Law Bill (Ley de Municipalidades).

The Municipal Law Bill aimed at devolving power from the national to municipal levels to promote development, as municipalities faced different problems that needed different solutions which could be targeted more efficiently locally. As part of this Law, municipalities became responsible for constructing, administering, and maintaining piped water and sewage networks, functions that were the responsibility of SANAA. However, the Law failed to clarify SANAA's functions. Therefore, the Municipal Law resulted in the duplicity of remits. Moreover, fear spread to the population that, because of the municipalities' lack of experience to operate water supply systems, they would be handed to private companies; therefore municipalization was just a step toward the privatization of the service [32].

In 1994, when the process of municipalization of the water networks had already started, the manager of SANAA opposed the process arguing that SANAA could become profitable and functional by reducing its personnel and creating regional centers [32]. By 1996, the lack of a solid national alliance among the different actors (municipalities, donor governments, users, and politicians) in favor of the reform led to its failure and only a few networks were municipalized [8]. 
The controversial issues of the Municipal Law were clarified in 2003 when the Water Supply and Sanitation (WSS) Sector Framework Law (Ley Marco del Sector Agua Potable y Saneamiento) was approved. The WSS Sector Framework Law produced the following changes in the water sector: (a) the creation of a coordinator agency, CONASA, which is responsible for establishing and approving policies, to develop strategies, define objectives, goals, and investment programs, as well as coordinating activities for improving the water and sanitation sector at a national level; (b) the creation of a regulator agency, ERSAPS, which is responsible for creating the mechanisms to regulate and control the providers of the sewage and water services at a national level; (c) the responsibility for providing the drinking water and sewage service was assigned to the municipalities; SANAA should transfer gradually, free of any debts, all systems and all their assets to the municipalities within 5 years. During the transition period, SANAA would continue to operate and administer the water systems under the regulation of ERSAPS, and in preparation for the takeover, provide technical and administrative training for the municipalities. After the transfer, it was proposed that SANAA would become a technical secretariat to support the municipalities, CONASA and ERSAPS.

The Framework Law also demands that SANAA pays compensation to all its employees who will be dismissed. The financial resources to cover these costs were supposed to be made available by the president. By 2008, the funding of these costs was still unresolved and a modification to the WSS Sector Framework Law was issued, identifying the need to find a way to finance the compensatory work benefits, as well as strategies for the technical-administrative training of the new providers of the service. An extension of five more years was granted to finalize the municipalization of the water sector in Tegucigalpa and to pay the work benefits of the employees, which add up to more than US\$35.5 million [33].

The endpoint to the rivalry was publicly announced in the local newspapers in 2010 when SANAA and the municipality declared that they will work together to face the actual water crisis in Tegucigalpa [34].

\subsection{Financial limitations}

According to the interviews, SANAA faced financial limitations which hindered investment in new sources of water or even to maintain the distribution network. The origin of its financial problems varied between interviewees. Some of the given reasons are: (a) the low price of the water service which only covers the direct costs of water potabilization and barely covers the employee payroll. Water prices are controlled by the Central Government and increases have only been approved when SANAA was unable to pay the salaries of its employees. (b) Excess of staff because SANAA employs more personnel than needed (14 employees per 1,000 connections in Tegucigalpa; the average for other cities in Honduras is four [35]). The origin of the excess staff was that, with every change of government, new employees are recruited for political reasons. Then, the trade union, SITRASANAAYS, will protect employees who have acquired a permanent position and do not hold a managerial position from being fired. It was expressed that this excess of personnel is draining the financial resources and compromises overall efficiency. (c) High physical and commercial losses were described as unquantifiable amounts of water being lost in the distribution network, either by theft or leakages, causing a financial burden to SANAA and which substantially compromises the overall water distribution. (d) The fact that the SANAA for Tegucigalpa, better known as the Metropolitan, subsidizes smaller non-profitable services in other municipalities due to the lack of decentralized administration. (e) The bad financial situation of SANAA limits its international borrowing capacity and thus the means to build a new reservoir. The Central Government could act as its accreditor but has not done so this far. So far, financial support from the national government 
had only been granted in the case of the unusually long dry season of 2010, which allowed SANAA to repair water distribution trucks and to carry out underground water exploration. (f) Projects targeting the improvement and maintenance of the water infrastructure depend on finding international funding.

The first reason explaining the lack of financial resources, the low price of the water service in Tegucigalpa, has been addressed by several researchers who have recognized that SANAA has had no opportunity to either expand or maintain the distribution network [8, 25, 36]. Strand [36] analyzed some of the consequences of the low prices of water: (a) low-income households with no access to piped potable water pay a higher actual price for water than households with such access that belong to higher-income groups, since their supply relies on private water vendors; (b) cheap water prices encourage those with easy access to use it excessively; (c) SANAA does not receive enough revenues to improve and maintain the water system, resulting in high water losses, poor service for those served, and reduced incentives to extend water to additional households.

SANAA has never had control over the price of the water service. Before 1991, the price was decided directly by the National Congress [8]. In 1991, the National Utility Board (Comisión Nacional Supervisora de Servicios Públicos, CNSSP) was created to establish prices for public services, but in reality it only set the price of the water service in response to political interests and was only subject to the approval of the National Government [36]. From 2003, after the approval of the WSS Sector Framework Law, the duty of approving a new price structure has been transferred to ERSAPS.

The excess of staff working in SANAA has been analyzed using the efficiency indicator of staff per 1,000 connections and also by observing the average annual cost of the labor force per connection. In developing countries, the best practice target of staff per 1,000 connections is five or less [37]. A high indicator is a result of the political interference in the water company's operation [8, 32, 37]. In the case of Tegucigalpa, Walker et al. estimated that in 1994, this indicator was in the order of 13.6 and the annual cost of labor per connection in Tegucigalpa is almost twice as much as the cost in the rest of the country. In 2003, it was calculated that the employees of SANAA at a national level absorb $70 \%$ of the utility budget and $60 \%$ of those employees work in Tegucigalpa [33].

The non-billed water lost in the distribution network either by theft or leakages is better known as unaccounted for water (UFW). UFW is defined as the difference between the amount of water pumped into the system and the water metered to customers [38]. High levels of UFW reflect the failure to repair leaks and meters, replace old pipes, detect illegal connections, implement good commercial practices, and meter all uses [39]. In the case of SANAA, the poor coverage of measuring devices makes it impossible to know how much water is lost. In 2005, only $51 \%$ of clients having piped water had measured consumption, the rest paid a fixed fee based on an expected average consumption [40]. Studies have estimated that the percentage of water lost ranges from 30\% [41] up to $61 \%$ [40]. Financially speaking, the volume of non-billed water can range from $46 \%$ during the months corresponding to the rainy season to negative values during the months corresponding to the dry season [40]. The explanation for this phenomenon lies within the flat rates and the intermittent water supply. During the dry season, SANAA would reduce the number of hours of service and the clients paying for an average consumption would still have to pay for a fixed volume of water that would not be received. Additionally, leakage does not occur if there is no water in the pipes. During the rainy season, the number of hours of service per day is increased; therefore, the consumption is higher and so is the volume that will be lost in leakages.

Another reason explaining the lack of financial resources is the fact that SANAA for Tegucigalpa, better known as the Metropolitan division, subsidizes other non-profitable regional centers in the 
country. SANAA possesses seven regional centers, each with relative autonomy in several aspects, such as finance, planning, and operation. The exception of the financial autonomy is the metropolitan division. Income produced by the service fees of Tegucigalpa is collected and administered by the central administration of SANAA. [42]. The reason for this exception was that Tegucigalpa, the biggest source of income of SANAA, could give financial support to other regional centers [32, 42]. This lack of autonomy goes against the principle of decentralization which created the regional centers in 1994.

The financial problems of SANAA were analyzed by Walker et al. in 2000 [8]. They described how SANAA is directly financed through the water tariff and how it benefits from a variety of subsidies through the Central Government. SANAA has become financially dependent on such benefits which are not enough to allow the necessary maintenance of the existing water infrastructure. They concluded that it was due to the inefficient use of the financial resources, rather than the lack of those, that SANAA has been incapable of expanding its coverage, based on the fact that during the years from 1989 to 1993 SANAA received 66\% of the national investment when it serves 23\% of national water connections [8]. Moreover, they describe how international development agencies use their resources to promote models which produce short-term improvements in the quality and coverage of the service, but which will not necessarily lead to a rational reorganization of the water sector, for some are supporting the regional centers of SANAA and others, the municipalities.

When municipalization of the water service takes place, several of the factors causing financial limitations will end. All of the employees of SANAA will be dismissed and SANAA will hand the water service free of debts to the municipality. The municipality of Tegucigalpa will no longer subsidize other municipalities, which, in spite of leaving poor communities in the rest of the country with a big problem, would allow the use of the financial resources for maintenance and investment of the local network. During the interviews, authorities from ERSAPS and CONASA reaffirmed that, once the municipalization takes place, the water service will be profitable without any increase of the actual price tariff as long as the municipality does not repeat the same mistake of recruiting more employees than needed.

\subsection{Interference of the central government and governmental agencies in the water sector}

A recurrent pattern during this research has been to indicate how the actions of the Central Government and governmental agencies have affected the performance of SANAA. The negative impact of the Central Government in the water sector of Tegucigalpa has been both direct and indirect.

Examples of a direct negative impact the Central Government has had on the water sector have been the control and politicization of the price of the water service, the reckless approval of a law which has created confrontation between SANAA and the municipality, and the loss of continuity in the running and planned programs due to the removal of key directives of SANAA at every change of political term.

Every four years a new president of Honduras is elected, without a chance of re-election. The newly elected president will appoint, among other positions, a new manager and sub-managers for SANAA. This frequent change of the senior management constitutes a serious obstacle to the continuation that should exist between planning and actions, for it is not possible to execute long-term plans and projects because every new administration wants to carry out its own plans [12].

The most notorious case in SANAA of this change of management resulting in a change of direction occurred in 1994. The manager at that time supported and had started the municipalization of the water services of different cities. However, that same year, this manager was replaced by a new one who started a reform of SANAA instead of the municipalization. The fact that the direction of 
SANAA could drastically change with a change of management demonstrates the lack of national policies and the personalization of the water sector [8].

Efforts have been made to eliminate the deleterious effects of the change of government with the approval of the Vision of the Country and the Plan of the Nation in 2010 by the National Congress. The Vision of the Country contains the national objectives and prioritized goals until 2038; the Plan of the Nation establishes the guidelines, objectives, and indicators until 2022, which is the first phase of the Vision of the Country. Representatives of all the political parties pledged to follow the document. Now, independent of the political party ruling the country, the Vision of the Country and the Plan of the Nation should be followed. Regarding the water sector, the Vision of the Country reaffirms the enforcement of the WSS Sector Framework Law, and it also establishes goals for coverage and quality of the service.

The indirect impact the Central Government has had on the water sector are the effects of what is known as the spoils system or patronage, whereby public jobs are used as rewards for political activity [43]. The effects patronage has had in SANAA are: (a) the financial weakening of SANAA due to the recruitment of unnecessary personnel; (b) the lack of a sense of identity among employees who realize their job is threatened in the next electoral period if the Trade Union is not protecting them; and (c) the loss of trained and highly qualified personnel for political reasons.

Patronage has become a common practice in the public administration of the whole country, and the municipalities are not an exception. Since the 1980s, the municipality of Tegucigalpa has had a severe financial crisis, which has been aggravated by the recruitment of political supporters [12]. During the interviews, several people expressed their concern that once the operation of the water service would be handed to the municipality, the spoils system would arise once again. It will be the duty of ERSAPS to prevent the recruitment of excess personnel for political reasons. The ideal situation for the whole country would be to ban patronage and replace it with a merit system, as has been done in other countries [43]. A merit system would bring, among other benefits, the recruitment of only the required personnel based on competence and would allow them to remain in their posts independent of their political affiliation, thus avoiding the unnecessary training costs and loss of continuation of projects.

In the case of the impact that the other governmental agencies have had on the performance of SANAA, the lack of coordination and the lack of vision to foresee the consequences of their decisions had repercussions on the water supply for Tegucigalpa. The failure of COHDEFOR to prevent construction in protected areas has now been transferred to SANAA who has to pay the compensatory expenses. The failure of SOPTRAVI to provide a design of a road project that would not jeopardize the quality of one of the main sources of water for Tegucigalpa has left SANAA paying higher costs for water treatment. Both situations have a financial impact on SANAA, whose finances are already weak.

Figure 1 summarizes the different points discussed throughout this paper describing how the actions of the central Government have hindered the proper planning and operation of SANAA leading to drinking water scarcity in Tegucigalpa.

\section{CONCLUSIONS}

This paper has analyzed and discussed the reasons that have lead to the water shortage in Tegucigalpa. The analysis has focused on the problems encountered by the National Water Utility, SANAA, as they have been in charge of the water supply of Tegucigalpa since 1960. Interviews revealed 13 distinct problems which, throughout the analysis, became interrelated revealing the complexity of the circumstances which have lead to an insufficient water supply in Tegucigalpa. The causes of the insufficient water supply can be found in the unsuitable environment in which SANAA is embedded. 


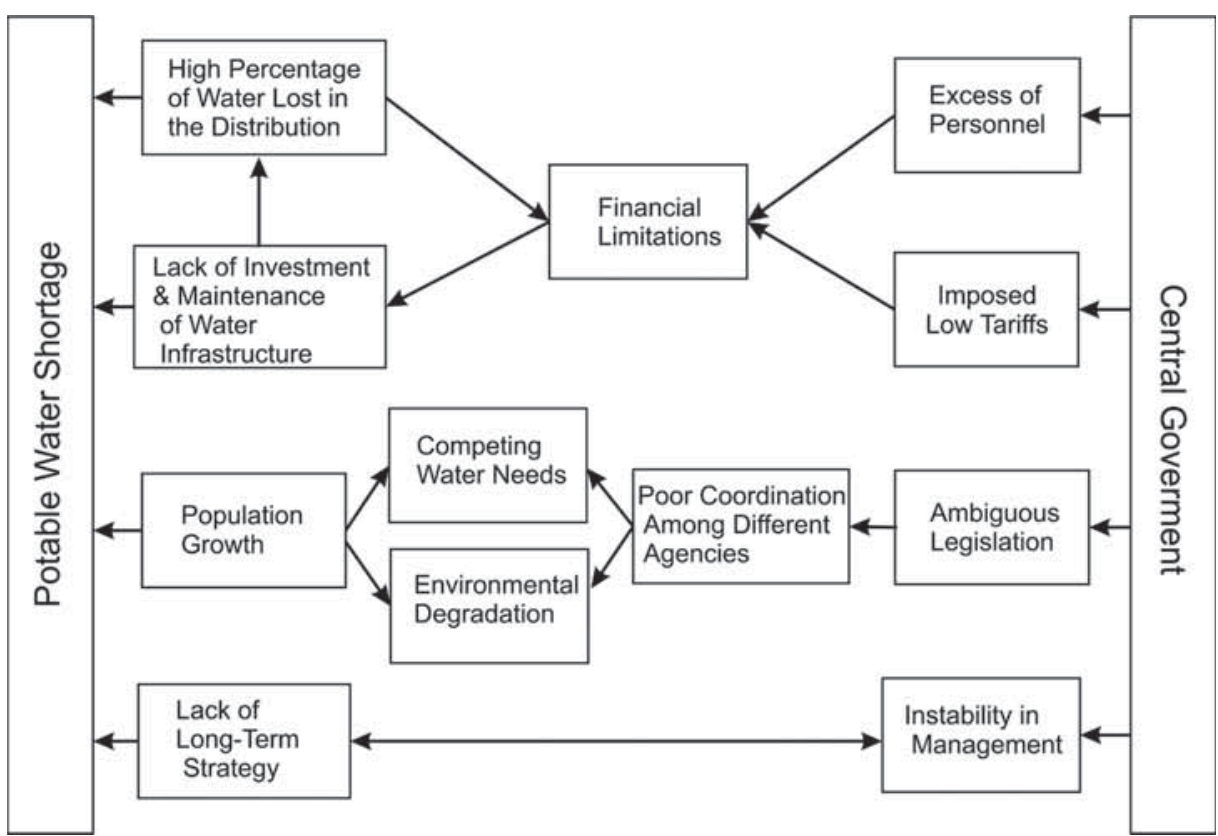

Figure 1: Diagram showing how the actions of Central Government have affected the potable water supply in Tegucigalpa directly and indirectly.

The first problem analyzed was the seasonality of rainfall. SANAA has to effectively administer the water stored in the reservoirs during the rainy season and ensure it lasts throughout the dry season. However, because SANAA provides water intermittently throughout the dry season, it is obvious that the stored volume is not sufficient anymore due to the lack of investment in water infrastructure.

SANAA has encountered financial limitations when trying to maintain or expand the water distribution network and when trying to build a new reservoir. The ageing pipes have leakages and therefore much of the water produced is lost and unaccounted for. The construction of a new reservoir has been highly compromised because SANAA has to pay high compensatory expenses to habitants living in the flood area and has no financial resources available to do so. Although these areas were supposed to be protected, the lack of coordination among agencies, on occasions created by ambiguous legislation, lead to the failure to protect these areas. While SANAA tries to find a source to finance the construction of the reservoir and the compensatory expenses attached to it, urban pressure, pollution, and competing uses of the available water resources are increasingly jeopardizing the feasibility of a new reservoir.

The financial limitations of SANAA have several causes. One is that a part of the funds from the tariffs in Tegucigalpa are redistributed to small non-profitable regional centers in the country instead of being reinvested locally. Other causes are closely linked to the Central Government when it controlled the price of potable water service and also introduced the patronage system in SANAA. The intrusion of political supporters in every presidential term has weakened the already fragile economy of SANAA. Likewise, patronage has prevented the long-term planning since the managers are changed every political term.

Although mistakes have been made in the past, actions have been taken to amend them. The Vision of the Country and the Plan of the Nation should provide continuity of the programs, 
independent of the political affiliation of the administration. The creation of an independent regulator, a supervisor, and operator of the water service may create a control and check relationship between different agencies. Some agencies which were failing previously have been restructured. However, if the leadership of the agency is constantly changed, plans will be unavoidably interrupted. The coordination of agencies is essential and the duties and responsibilities of each must be defined. Finally the municipality, as the new provider of the service, will need to be aware that the welfare of Tegucigalpa cannot be sacrificed for the benefit of political supporters. If the conditions highlighted by this paper are ignored, the population of Tegucigalpa will continue to suffer from water shortages year after year.

\section{ACKNOWLEDGMENTS}

This work was funded by the Swedish International Development Agency. The authors would like to thank the staff from SANAA, ERSAPS, CONASA and AMITIGRA for their collaboration during this investigation. The authors would also like to thank Stella Lowder, Jan Erik Gustafsson, Patricia Phumpiu, and the two reviewers for their valuable contribution to this paper.

\section{REFERENCES}

[1] Schwartz, K., The reform of public water utilities: successful utility reform efforts as punctuated equilibria. Water Policy, 11(4), pp. 401-412, 2009. doi: http://dx.doi.org/10.2166/ wp.2009.062

[2] Swyngedouw, E., The contradictions of urban water provision: a study of Guayaquil, Ecuador. Third World Planning Review, 17(4), pp. 387-406, 1995.

[3] Foster, V., Policy Issues for the Water and Sanitation Sectors, IDB: Washington, D.C, 1996.

[4] Mugabi, J., Kayaga, S. \& Njiru, C., Strategic planning for water utilities in developing countries. Utilities Policy, 15(1), pp. 1-8, 2007. doi: http://dx.doi.org/10.1016/j.jup.2006.10.001

[5] Spiller, P. \& Savedoff, W., Oportunismo Gubernamental y Suministro de Agua, in Agua Perdida, eds. P. Spiller \& W. Savedoff, Inter-American Development Bank: Washington. pp. 1-39, 2000.

[6] Van der Bruggen, B., Borghgraef, K. \& Vinckier, C., Causes of water supply problems in urbanised regions in developing countries. Water Resources Management, 24(9), pp. 1885-1902, 2010. doi: http://dx.doi.org/10.1007/s11269-009-9529-8

[7] OPS/OMS, Analisis del Sector Agua Potable y Saneamiento en Honduras. 2003, Agencia Suiza para el Desarrollo y la Cooperación (COSUDE), Banco Interamericano de Desarrollo (BID), Programa de Agua y Saneamiento/Banco Mundial (PAS-BM), Agencia Internacional de Desarrollo de los Estados Unidos (USAID), Organización Panamericana de la Salud/Organización Mundial de la Salud (OPS/OMS), Agencia Sueca para el Desarrollo Internacional (ASDI), Fondo de las Naciones Unidas para la Infancia (UNICEF), Servicio Nacional de Acueductos y Alcantarillados (SANAA), Ministerio de Salud, Grupo Colaborativo de Agua y Saneamiento de Honduras: Tegucigalpa.

[8] Walker, I.M., Velásquez Ordoñez, F. \& Rodriguez, F., Esfuerzos de Reforma y Equilibrio de Bajo Nivel en Sector de Agua de Honduras, in Agua Perdida: Compromisos Institucionales para el Suministro de Servicios Públicos Sanitarios, eds. P. Spiller, W. Savendof, InterAmerican Development Bank: Washington, D.C. pp. 41-99, 2000.

[9] INE, Trigésima Quinta Encuesta Permanente de Hogares Septiembre 2007 in EPHPM $X X X V$., Instituto Nacional de Estadística de Honduras: Honduras, 2007. 
[10] OIRSA, Descripción de Embalses de Honduras, OIRSA, ed. Organismo Internacional Regional de Sanidad Agropecuaria, 2007.

[11] Coello-Balthasar, Z., Phumpiu, P., Balfors, B \& Gustafsson, J.E. Assessment of Causes Leading to an Insufficient Water Supply in Tegucigalpa, Honduras, in Water Resources Management VI, eds. C.A. Brebbia \& V. Popov, WIT Press: California, USA, 2011. doi: http://dx.doi. org/10.2495/WRM110031

[12] Caballero, E., Gestion Urbana y Participación Popular en la Ciudad de Tegucigalpa en la Década de los 80, ed. M. CSUCA, UNO+UNO Consultores., Tegucigalpa: Ediciones Zas, 1992.

[13] SANAA, Redistribucion de Horarios de Servicio de Agua Potable, in Diario La Tribuna. Tegucigalpa, 2010.

[14] World Bank, Honduras - Reporte de pobreza : logrando la reduccion de la pobreza - Reporte principal, Departamento de América Central Región de América Latina y el Caribe del Banco Mundial, 2006.

[15] Vairavamoorthy, K., Gorantiwar, S.D. \& Mohan S., Intermittent water supply under water scarcity situations. Water International, 32(1), pp. 121-132, 2007. doi: http://dx.doi.org/ $\underline{10.1080 / 02508060708691969}$

[16] Yin, R., Case Study Research: Design and Methods. Fourth Edition. SAGE Publications: California, 2009.

[17] Frankfort-Nachmias, C. \& Nachmias, D., Research Methods in the Social Sciences. Oxford University Press Inc: New York, 1996.

[18] Russell, H., Social Research Methods: Qualitative and Quantitative Approaches. SAGE Publications: California, 2000.

[19] Patton, M., Qualitative Research \& Evaluation Methods. Third Edition. SAGE Publications: California, 2002.

[20] Westerberg, I., Walter, A., Guerrero, J-L., Coello, Z., Halldin, S., Xu, C-Y., Chen, D \& Lundin L-C., Precipitation data in a mountainous catchment in honduras: quality assessment and spatiotemporal characteristic. Theoretical and Applied Climatology, 101(3), pp. 381-396, 2010. doi: http://dx.doi.org/10.1007/s00704-009-0222-x

[21] Angel, S., Bartley, K., Derr, M., Malur, A., Mejia, J., Nuka, P., Perlin M., Sahai, S., Torrens, M. \& Vargas, M., Rapid Urbanization in Tegucigalpa, Honduras. Preparing for Doubling of the City's Population in the Next Twenty-five Years, Princeton University: New Jersey, 2004.

[22] Pearce-Oroz, G., Causes and Consequences of Rapid Urban Spatial Segregation: The New Towns of Tegucigalpa, in Desegregating the City: Ghettos, Enclaves, and Inequality, ed. D. Varady, State University of New York Press: Albany, NY, 2005.

[23] Ortiz, A., Latin America \& the Caribbean - Urban services delivery and the poor: the case of three Central American cities. World Bank: Washington DC. p. 132, 2002.

[24] SANAA, Estudio de Rehabilitación Ambiental en Cuatro Subcuencas Hidrográficas del Sistema de Abastecimiento de Agua Potable para Tegucigalpa. ESA Consultores, C. Lotti \& Associati: Tegucigalpa, 2005.

[25] Lee, M., Multiple Resource Needs and Multiple Conflicts in Urban Watersheds in Developing Countries: The Case Study of the Guacerique Watershed, Tegucigalpa, Honduras, in Integrated Management of Surface and Groundwater. UCOWR Annual Meeting. San Antonio, Texas, 1996.

[26] JICA, Informe del Estudio Preliminar sobre el Proyecto de Abastecimiento de Agua para el Area Urbana de Tegucigalpa. Agencia de Cooperación Internacional del Japón, 2006. 
[27] Berrios, F., Dictan sentencia definitiva a favor de Mountain Chalets in El Heraldo: Tegucigalpa, 2008.

[28] Calix, G., SANAA se opone rotundamente a que se habilite Ciudad Mateo, in El Heraldo: Tegucigalpa, 2009.

[29] Berrios, F., Guacerique II, de Nuevo un Proyecto Prioritario, in El Heraldo: Tegucigalpa, 2010.

[30] Medina, A., Suman 470 las Obras Paralizadas en la Capital, in El Heraldo: Tegucigalpa, 2009.

[31] Berrios, F., SANAA multará a constructoras en Honduras, in El Heraldo: Tegucigalpa, 2009.

[32] SITRASANAAYS, SANAA, Una Experiencia Novedosa, ed. P.R. Rigoberto. Tegucigalpa: Guardabarranco, Editorial y Litografía, 1998.

[33] CONASA, Plan Estratégico de Modernización del Sector Agua Potable y Saneamiento (PEMAPS). Tegucigalpa, 2006.

[34] Barahona, L., Crisis de Agua une al SANAA y a la Alcaldía, in El Heraldo: Tegucigalpa, 2010.

[35] ERSAPS, Agua y Saneamiento en Honduras Indicadores. Edición 2009. ERSAPS: Tegucigalpa, 2009.

[36] Strand, J., Water Pricing in Honduras: A Political Economy Analysis, in The Political Economy of Water Pricing Reforms, A. Dinar, ed., Oxford University Press for the World Bank: Oxford. p. 405, 2000.

[37] Tynan, N \& Kingdom, B., A Water Scorecard. Setting Performance Targets for Water Utilities. The World Bank Group: Washington DC, 2002.

[38] Koch, P., Water Sources: Principles and Practices of Water Supply Operations, ed. L. Bevard. American Water Works Association: Denver. p. 192, 2010.

[39] Yepes, ed. G., Infrastructure Maintenance in LAC: The Costs of Neglect and Options for Improvement, G. Yepes: World Bank, 1992.

[40] Hermida, A., Análisis de los Sistemas de Acueducto y Alcantarillado de la Ciudad de Tegucigalpa, Honduras, Banco Interamericano de Desarrollo (BID): Bogotá, Colombia, 2006.

[41] SOGREAH, Informe Inicial - Volumen 1 Estudio de Factibilidad, in Proyecto de Abastecimiento de Agua para Tegucigalpa, SANAA, 2003.

[42] PCI, Estudio del Sistema de Abastecimiento de Agua para el Area Urbana de Tegucigalpa en la Republica de Honduras, Informe Final, Informe Principal. Pacific Consultants International (PCI), Agencia de Cooperacion Internacional de Japon (JICA), Secretaría Técnica de Cooperación Internacional (SETCO), Servicio Autonomo Nacional de Acueductos y Alcantarrillados (SANAA). p. 189, 2001.

[43] Simon, H., Smithburg, D \& Thompson V., Public Administration. Transaction Publishers: New Jersey, p. 582, 1991. 